\title{
Strategi Pengembangan Sumber Daya Manusia Melalui Pendidikan dan Pelatihan pada Kantor Dinas Tenaga Kerja Kota Makassar
}

\author{
Putri Anna Nirwan', Risma Niswaty ${ }^{2}$, Jamaluddin $^{3}$, Rudi Salam ${ }^{4}$ \\ 1,2,,3Universitas Negeri Makassar \\ Email: annan.putri@gmail.com
}

\begin{abstract}
This study aims to determine the strategy of developing human resources through education and training at the Makassar City Manpower Office. Using a qualitative descriptive approach. The main instrument in this study is the researcher himself using a cellphone, and using a field note that is by recording data related to research found in the field. Data collection was carried out by using observation, interview, and documentation techniques. Analysis of the data used is data reduction, data presentation and conclusions. The results showed that the strategy of developing human resources through education and training at the Makassar City Manpower Office was in a fairly good category, seeing the focus in this study, namely: 1) determining needs has been determined quite well, 2) determining targets that are in in the good enough category, 3) the determination of the program content is in the good enough category, 4) the principles of learning get pretty good results, 5) the implementation of the program gets pretty good results, 6) identification of the benefits of getting pretty good results, and 7 ) the evaluation of program implementation got quite good results.
\end{abstract}

Keywords: Work Motivation, Employee Performance

\begin{abstract}
Penelitian ini bertujuan untuk mengetahui strategi pengembangan sumber daya manusia melalui pendidikan dan pelatihan pada Kantor Dinas Tenaga Kerja Kota Makassar. Dengan Menggunakan pendekatan deskriptif kualitatif. Instrument utama dalam penelitian ini adalah peneliti sendiri dengan menggunakan alat bantu handpone, dan menggunakan catatan lapangan yaitu dengan mencatat data yang terkait dengan penelitian yang ditemukan dilapangan. Pengumpulan data yang dilakukan dengan teknik observasi, wawancara, dan dokumentasi. Analisis data yang digunakan adalah reduksi data, penyajian data dan kesimpulan. Hasil penelitian menunjukkan bahwa strategi pengembangan sumber daya manusia melalui pendidikan dan pelatihan pada Kantor Dinas Tenaga Kerja Kota Makassar berada dalam kategori cukup baik, melihat fokus dalam penelitian ini, yaitu: 1) penentuan kebutuhan telah ditetapkan dengan cukup baik, 2) penentuan sasaran yang berada dalam kategori cukup baik, 3) penetapan isi program berada dalam kategori cukp baik, 4) prinsip-prinsip belajar mendapatkan hasil yang cukup baik, 5) pelaksanaan program mendapatkan hasil yang cukup baik, 6) identifikasi manfaat mendapatkan hasil yang cukup baik, dan 7) penilaian pelaksanaan program mendapatkan hasil yang cukup baik.
\end{abstract}

Kata Kunci: Motivasi Kerja, Kinerja Pegawai

\section{PENDAHULUAN}

Manajemen merupakan suatu perangkat terpenting dalam suatu organisasi, yang mana merupakan sebuah kegiatan perencanaan, proses, dan cara untuk menggerakkan seluruh elemen sumber daya yang ada pada sebuah organisasi atau instansi (Greasley, 2008; Neal, 2009; Robbins \& Coulter, 2012). Terdapat beberapa unsur manajemen yang terdapat didalamnya, yaitu, manusia, uang, cara, logistik, dan pasar. Dari beberapa unsur manajemen tersebut, sumber daya manusia adalah suatu hal yang kemudian sangatlah berpengaruh dalam ruang lingkup kerja dan produksi sebuah organisasi(Ferris et al., 2007; Suhariadi, 2013; Todericiu et al., 2014).
Masalah tentang SDM adalah problem yang kemudian dianggap biasa dan juga sekaligus rumit, dalam hal ini banyak orang yang menyatakan dalam bentuk teoritis, namun dalam realita/kenyataannya sangat sulit untuk direalisasikan. Masalah SDM, menjadi perhatian dari semua organisasi, baik itu organisasi bisnis maupun publik (Blaga \& Jozsef, 2014; Singodimendjo, 2011; Sulistiyani \& Rosidah, 2013). Hal ini dapat dimaklumi karena manusia merupakan unsur yang sangat penting dalam organisasi, di samping unsur yang lain (Nasrullah et al., 2018; Saggaf et al., 2014; Salam, 2015). Karena manusialah yang menciptakan pemikiran, 
karya atau produk yang kemudian dapat mengembangkan suatu kelompok.

Menurut (Bangun, 2016), sumber daya manusia merupakan suatu perangkat organisasi yang harus selalu diperbaharui baik dalam pendidikannya, pengetahuannya, maupun perilakunya itu sendiri. Dalam rangka pencapaian tujuan yang ideal, pelatihan (training) adalah suatu proses memperbaiki keterampilan kerja karyawan untuk membnatu pencapaian tujuan perusahaan (Bertram et al., 2015; Ouellet \& Vézina, 2014; Ozkeser, 2019).

Dalam Undang-Undang Republik Indonesia Nomor 05 tahun 2014 tentang Aparatur Sipil Negara (ASN), yaitu: a) Manajemen

PNS, meliputi: penyususnan dan penetapan kebutuhan, pengadaan, pangkat dan jabatan, pengembangan karier, pola karier, promosimutasi, penilaian kinerja, penggajian dan tunjangan, penghargaan, disiplin, pemberhentian, jaminan pensiun dan jaminan hari tua, perlindungan; b) Manajemen PNS pada instansi pusat dilaksanakan oleh pemerintah pusat sesuai dengan ketentuan peraturan perundangundangan; c) Manajemen PNS pada instansi daerah dilaksanakan oleh pemerintah daerah sesuai dengan ketentuan peraturan perundangundangan.

Dalam pelaksanaan pembinaan dan pengembangan SDM melalui pendidikan dan pelatihan, pemerintah cukup cepat memanifestasikannya dalam berbagai program (Hanrahmawan, 2012; Ningsi et al., 2016; Rakib et al., 2016). Pemerintah memberikan perhatian khusus pada kualitas pendidikan dan pelatihan aparatur sipil negara dalam menanggapi tuntutan lingkungan yang semakin kompleks, baik itu tuntutan, permintaan pasar dalam negeri maupun secara global. Dari aspek pendidikan, Pemerintah dalam mengupayakan pengembangan sumber daya manusia, salah satu jalan yang ditempuh adalah dengan menyelenggarakan pendidikan formal mulai dari pendidikan dasar, pendidikan menengah, dan perguruan tinggi (Yulianti et al., 2019) .

Seperti itu pula dinas tenaga kerja kota Makassar sebagai sebuah satuan kerja perangkat daerah yang memiliki tugas dan wewenang untuk membantu masyarakat dalam menyelenggarakan urusan di bidang ketenagakerjaan, hal ini senantiasa dituntut untuk mampu memaksimalkan tugas dan fungsi pokok yang diembannya. Maka Dari itu kebijakan peningkatan kualitas kompetensi pegawai pada Dinas Tenaga Kerja Kota Makassar diupayakan mengacu kepada tujuan organisasi yang dilaksanakan secara terarah. Untuk memenuhi maksud dan tujuan tersebut di atas, dinas tenaga kerja kota makassar melaksanakan pendidikan, pelatihan, mutasi pegawai, dan pengembangan karir pegawai yang disesuaikan dengan pendidikan yang dimiliki.

Terkhusus untuk pelaksanaan pembinaan dan pengembangan sumber daya manusia melalui pendidikan dan pelatihan, nampaknya respons pemerintah cukup cepat seperti dimanifestasikan dalam berbagai program. telah ditanamkan program pendidikan formal, dan pelatihan keterampilan di berbagai bidang bagi publik yang membutuhkan. Dalam menghadapi era globalisasi tidak hanya dibutuhkan kesiapan sumberdaya manusia yang siap bekerja, melainkan juga harus mampu mempersiapkan dan membuka lapangan kerja sehingga dapat mengurangi jumlah pengangguran (Inanna et al., 2019). Pada organisasi publik, berbagai tipe training atau pendidikan dan latihan telah dibentuk atau diaktifkan kembali, seperti peningkatan loyalitas pegawai negeri, training yang bersifat teknis dan fungsional, administrasi dan manajemen, ilmu dan teknologi, dan bidangbidang khusus.

Demikian pula halnya pada Dinas Tenaga Kerja Kota Makassar sebagai satuan kerja perangkat daerah yang mempunyai tugas membantu walikota dalam meningkatkan sumber daya manusia yang lebih baik. Berdasarkan hasil pengamatan awal terdapat beberapa masalah yang muncul, adapun masalahnya adalah terdapat $20 \%$ dari aparatur SDM yang menduduki posisi/jabatan tidak sesuai dengan pendidikan SDM tersebut, dan ada pula masalah yang kedua yaitu terdapat beberapa pegawai yang belum pernah diikutkan dalam pendidikan dan pelatihan (DIKLAT) sedangkan pegawai tersebut belum sepenuhnya menguasai keterampilan kerjanya.

\section{METODE PENELITIAN}

Penelitian ini menggunakan deskriptif kualitatif dengan fokus penelitian untuk mengetahui strategi pengembangan sumber daya manusia melalui pendidikan dan pelatihan pada Kantor Dinas Tenaga Kerja Kota Makassar. Adapun deskripsi fokus dalam penelitian ini adalah penentuan kebutuhan, penentuan sasaran, penetapan isi program, prinsip-prinsip belajar, pelaksanaan program, identifikasi manfaat dan penilaian pelaksnaan program.

Sumber data dalam penelitian ini ada dua, yaitu sumber data primer: merupakan data yang 
diperoleh dari hasil wawancara (informan) yang berisi pertanyaan berkaitan dengan pengembangan sumber daya manusia melalui pendidikan dan pelatihan (DIKLAT), adapun informan utama penelitian ini adalah Kepala Sub Bagian Umum dan Kepegawaian Kantor Dinas Tenaga Kerja Kota Makassar, sedangkan informan biasa/pendukung dalam penelitian ini adalah dua orang pegawai Dinas Tenaga Kerja Kota Makassar yang pernah mengikuti (DIKLAT).

Teknik pengumpulan data dalam penelitian ini, yaitu observasi, wawncara dan dokumentasi. Teknik analisis data yang digunakan adalah reduksi data, yaitu: dengan mencatat semua informasi yang diperoleh dari hasil wawancara. Informasi yang diperoleh kemudian dikumpul dan dipilih informasi-informasi yang dibutuhkan, setelah semua data yang diperlukan terkumpul maka dibuatlah abtraksi atau rangkuman; penyajian data, yaitu: penyajian dengan mengambil data yang pokok-pokok namun dapat dijamin kesahihannya. Dalam penyajian data, informasi yang telah dikumpulkan kemudian disusun untuk memudahkan menyusun kesimpulan; penarikan kesimpulan, yaitu: menarik permasalahan sehingga memungkinkan verifikasi selama penelitian berlangsung

\section{HASIL DAN PEMBAHASAN}

\section{Penentuan Kebutuhan}

Penentuan kebutuhan menjadi hal penting dalam peningkatan sumber daya manusia. Menentukan kebutuhan harus dilakukan dalam masing-masing individu untuk megikuti pengembangan SDM melalui pendidikan pelatihan, karena apabila pegawai yang akan mengikuti DIKLAT tidak menentukan kebutuhan maka akan tidak bisa diikutkan dalam pengembangan SDM tersebut apabila pengembangan SDM tersebut mempunyai kebutuhan yang harus dipenuhi terlebih dahulu.

Hasil wawancara menunjukkan bahwa penentuan pegawai yang akan diikutkan DIKLAT tersebut tergantung masing-masing bidangnya. dan berdasarkan surat edaran kementrian terkait permintaan pegawai yang akan diikutkan diklat berdasarkan tufoksinya. dan terdapat pula batasan umur. Jadi tidak serta merta pimpinan mengirim pegawai untuk diikutkan dalam program tersebut. Telah banyak pegawai yang telah diikutkan dalam program diklat sesuai ketentuan yang telah di tetapkan dengan tupoksi dan bidangnya masing-masing. dalam hal ini sudah menjadi tugas organisasi dalam mengembangkan Sumber Daya Manusia yang terdapat di dalamnya.

Lebih lanjut hasil wawancara menjelaskan bahwa berdasarkan surat edaran dari kementrian terkait pegawai yang akan diikutkan diklat, pimpinan merekomendasikan berdasarkan formasi PNS dan kebutuhan pada organisasi itu sendiri, karena pegawai diminta untuk mengikuti diklat itu memang bukan karena kemauan sendiri sehingga kami diikutkan dalam program diklat melainkan kebutuhan organisasi itu sendiri. Pimpinan menentukan pegawai yang akan diikutkan diklat itu tidak adanya pendekatan yang berlebih ataupun terjadinya nepotisme, melainkan pimpinan memilih pegawai untuk diikutkan diklat itu berdasarkan kebutuhan pegawai. Misalnya untuk seorang pegawai menduduki pejabat eselon empat (4) maka harus mengikuti diklat sesuai dengan kedudukannya.

Berdasarkan keterangan yang diperoleh peneliti dari beberapa hasil wawancara dan observasi yang dilakukan dapat disimpulkan bahwa pelaksanaan program dari dinas tenaga kerja kota Makassar dalam pengembangan SDM pada aspek penentuan kebutuhan sudah tergolong cukup baik. Karena melihat cara pimpinan menentukan pegawai yang akan diikutkan dalam program diklat harus berdasarkan surat edaran kementrian, sesuai dengan kebutuhan pegawai dan organisasi dan terdapat pula batasan umur bagi pegawai yang akan diikutkan dalam program diklat tersebut, jadi pimpinan tidak serta merta mengikutkan pegawai dalam program diklat jika tidak sesuai dengan apa yang telah di tetapkan.

\section{Penentuan Sasaran}

Penentuan sasaran merupakan faktor utama yang dilakukan apabila suatu individu/organisasi melakukan suatu kegiatan/tahap pembelajaran harus adanya penentua sasaran, target atau faktor apa yang ingin dicapai maupun diketahui dalam melakukan suatu kegiatan tersebut. Hal ini dikaitkan dengan sumber daya manusia yang mengikuti diklat dengan mempunyai dan menentukan sasaran yang ingin di capai setelah mengikuti program diklat tersebut. Sasaran tersebut bisa menjadi sebuah keberhasilan yang dicapai setelah mengikuti suatu kegiatan.

Berdasarkan hasil wawancara dengan informan, bahwa sebelum pimpinan menilai secara pribadi terlebih dahulu, mengenai pegawai yang telah mengikuti program diklat tersebut dari kementrian akan diberikan sertifikat untuk pegawai yang telah mengikuti diklat. Dengan di berikannya sertifikat berarti pegawai tersebut 
dikatakan telah berhasil mengikuti program diklat tersebut. Dan penilaian pimpinan secara pribadi terhadap pegawai yang telah mengikuti diklat terdapat peningkatan dalam melaksanakan tufoksinya. dan tentu pegawai yang telah mengikuti diklat ada kemampuan lebih dari sebelum mengikuti diklat, paling tidak pegawai tersebut bisa mengaplikasikan apa yang di peroleh setelah diklat.

Selanjutnya berdasarkan hasil wawancara bahwa terdapat perubahan yang dirasakan oleh pegawai yang telah mengikuti diklat. Setidaknya pola fikir, kemampuan dalam menjalankan tugas bisa berubah menjadi lebih baik setelah mengikuti program diklat. Karena dalam program pelatihan peserta banyak mengambil pelajaran yang menyangkut pengembangan seorang pegawai/SDM dalam menjalankan sebuah tugas apa yang menjadi tanggung jawab di setiap individu.

Seorang pegawai yang mengikuti program diklat tentu untuk adanya pengembangan dalam hal dalam bekerjanya atau biasa dikatakan peningkatan SDM, hal ini mengenai tahap lanjutan untuk pegawai yang telah mengikuti diklat sudah tidak ada lagi tahap selanjutnya karena didalam program diklat pegawai/peserta sudah mendpatkan ilmu yang lebih banyak, jadi tinggal bagaimana pegawai tersebut bekerja secara lebih baik dari hasil yang di dapatkan setelah mengikuti diklat tersebut. Namun apabila pegawai tersebut dianggap terlalu lama sudah mengikuti diklat maka dilakukan program diklat yang namanya diklat up grading (penyegaran).

Beberapa hasil rekapan wawancara ynag telah diurakan maka dapat disimpulkan bahwa pengembangan sumber daya manusia melalui pendidikan dan pelatihan pada Kantor Dinas Tenaga Kerja Kota Makassar pada aspek penentuan sasaran cukup baik, karena pimpinan melihat pegawai yang diikutkan dalam program pendidikan dan pelatihan tepat pada sasaran apa yang akan dituju/dicapai dan terdapat pula peningkatan yang baik dalam kinerjanya.

\section{Penetapan Isi Program}

Dalam mengikuti program pendidikan dan pelatihan Penetapan isi program merupakan harus jelas adanya apakah isi program tersebut sesuai dengan program diklat yang diikuti. Karena program diklat yang diikuti seorang pegawai itu harus sesuai bidang dan keahlian pegawai atau peserta tersebut. Hasil wawancara menjelaskan, bahwa materi atau isi dari program diklat sesuai dengan bidang/kompetensi masing-masing peserta pelatihan, karena dimana pelatihan ini salah satu tujuannya untuk mengembangkan suatu keterampilan yang sudah dimiliki oleh para peserta. Jadi tentu isi/materi yang didapatkan ataupun diberikan dari penyaji materi tidak terlepas dari apa yang menjadi tugas dan tanggung jawab di dalam suatu organisasinya. Contoh seorang pegawai yang menduduki jabatan di bidang Mediasi, Maka dalam pelatihan tersebut juga mengenai Mediasi Tersebut.

Berdasarkan dari dua informan diatas bahwa dapat disimpulakn upaya yang dilakukan dari pihak pengembangan SDM melalui pendidikan dan pelatihan sudah cukup baik karena melihat isi dari program pengembangan SDM sesuai dengan keberhasilan yang akan dicapai oleh para peserta pelatihan tersebut.

\section{Prinsip-prinsip belajar}

Pada akhirnya, hasil yang dicapailah yang dapat digunakan sebagai tolok ukur tentang tepat tidaknya prinsip-prinsip belajar yang diterapkan dalam suatu program pelatihan dan pengembangan. Dengan kata lain, yang diharapkan terjadi ialah berlangsungnya proses belajar dengan cepat karena peserta pelatihan dan pengembangan merasa bahwa prinsip belajar yang di terapkan tepat. Pada dasarnya dalam belajar maupun bekerja semua orang pasti mempunyai prinsip belajar, namun terkadang prinsip belajar itu dapat berubah karena adanya pelajaran baru, pengaruh atau masukan dari orang lain.

Hasil wawancara mengenai perubahan prinsip belajar, bahwa dalam kegiatan pendidikan dan pelatihan tentu disampaikan bagaimana prinsip belajar yang baik, dalam hal ini metode belajar yang digunakan agar tujuan pembelajaran tepat sasaran artinya hasil yang ingin dicapai itu baik dan berhasil. Jadi peningkatan pelatihan pengembangan ini memberikan pengaruh kepada perubahan prinsip belajar peserta, karena sebelum peserta mengikuti diklat prinsip belajar mereka seperti biasa saja dan kemudian peserta telah mengikuti diklat didalam pendidikan dan pelatihan itu peserta disampaikan bahwa prinsip belajar yang tepat digunakan sebaiknya seperti ini ketika mereka menerapkan prinsip belajar baru yang telah diberikan tentu terjadi perubahan prinsip-prinsip yang digunakan sebelum mengikuti diklat dan setelah mengikuti diklat, jadi terdapat pengaruh yang besar.

Lebih lanjut dalam hidup manusia dituntut untuk harus banyak belajar, karena dari belajar kita dapat banyak mengetahui apa yang belum diketahui dari sebelumnya. Setelah mengikuti 
pelatihan pengembangan di dalamnya terdapat banyak pelajaran baru yang didapat, karena dipertemukan dari suku dan ras yang berbeda dan terdapat perbedaan prinsip belajar pula nah disitulah peserta dapat merubah prinsip belajarnya.

Beberapa pendapat di atas dan hasil observasi yang dilakukan peneliti, dapat disimpulkan bahwa upaya dalam meningkatkan SDM melalui pendidikan dan pelatihan SDM pada aspek perubahan prinsip-prinsip belajar sudah cukup baik. Hal ini dapat dibuktikan dengan adanya pernyataan para pegawai yang telah mengikuti pelatihan bahwa setetelah mengikuti pelatihan pengembangan SDM prinsip belajar pegawai tersebut berubah menjadi lebih baik.

\section{Palaksanaan Program}

Dalam melaksanakan program pelatihan pengembangan SDM tentu terdapat kepentingan organisasi maupun peserta, apabila seseorang berusaha pasti akan terdapat/menginginkan hasil yang ingin dicapai di dalam melaksanakan program pelatihan pengembangan tersebut. Hasil wawancara mengenai kepentingan organisasi dalam pegawai yang mengikuti pendidikan dan pelatihan menjelaskan bahwa terdapat kepentingan organisasi dalam mengikutkan pegawai/SDM dalam pelatihan pengembangan, karena selain dari tufoksinya organisasi memang memerlukan dan mengharapkan pegawai yang berkompeten didalam melaksanakan tugasnya maupun bagi organisasinya karena Dinas Tenaga Kerja Kota Makassar ini merupakan salah satu instansi yang banyak diberikan tugas oleh wali kota untuk pelayanan publik hususnya dibidang ketenagakerjaan maka pegawai harus dituntut lebih banyak mengetahui dan menguasai ilmuilmu ketenagakerjaan.

Selanjutnya, berdasarkan hasil wawancara mengenai pengembangan SDM melalui aspek pelaksanaan program dalam kepentingan pegawai dalam mengikuti pelatihan, bahwa selain untuk kepentingan organisasi peserta mengikuti pelatihan pengembangan juga tentu mempunyai kepentingan pribadi seperti untuk mendapatkan inovasi ataupun hal lain yang memang seorang peserta ingin dapatkan secara pribadi. Entah itu yang di dapatkan dari materi pelatihan maupun yang di dapatkan dari lingkungan sekitar selama mengikuti pelatihan pengembangan, karena dimana kita mengenal seseorang baru pasti terdapat pula pelajaran baru.

Berdasarkan keterangan dari beberapa informan tersebut, hal itu dapat dibuktikan dari hasil pengamatan yang dilakukan dilapangan terlihat bahwa upaya yang dilakukan peserta pelatihan pengembangan dalam aspek pelaksanaan program dengan melihat tujuan pribadi peserta untuk mengikuti pengembangan SDM melalui DIKLAT itu sendiri sehingga dapat dilihat dampak baik bagi peserta yang telah mengikuti DIKLAT tersebut.

\section{Identifikasi manfaat}

Identifikasi manfaat adalah suatu langkah yang dilakukan untuk mengidentifikasi, meneliti, mencari dan mengumpulakn untuk menemukan berbagai ragam manfaat yang telah dicapai dalam program pelatihan pengembangan SDM. Hasil wawancara menjelaskan bahwa manfaat yang diperoleh bagi organisasi dalam mengikutkan pegawai dalam program DIKLAT menjadikan sumber daya manusia yang lebih sehingga memudahkan suatu organisasi mencapai tujuannya. Selain itu hasil wawancara tentang hasil/manfat yang di peroleh setelah mengikuti pelatihan pengembangan SDM, tentu mendapat banyak manfaat seperti mendapat wawasan, pengetahuan, pengalaman dan pelajaran baru yang didapatkan, terlebih dalam menjalankan tugas pasti lebih terdapat pengembangan dalam kinerja menjadi lebih baik, dan lebih cepat dalam mengerjakan tugas, karena dimana dalam mengikuti DIKLAT memang kita di tuntut untuk harus lebih banyak atau lebih ahli dalam hal mengerjakan tugas di banding pegawai yang belum mengikuti pelatihan pengembangan SDM sehingga seorang pegawai yang telah mengikuti DIKLAT.

Berdasarkan dari beberapa pendapat dan hasil observasi di atas, dapat disimpulkan bahwa upaya yang di peroleh pegawai/peserta dalam pengembangan SDM melalui pendidikan dan pelatihan terdapat banyak manfaat yang di peroleh. Hal ini dapat dilihat dari peningkatan SDM yang dapat menyelesaikan tugas dengan lebih baik dan lebih cepat.

\section{Penilaian Pelaksanaan Program}

Penilaian pelaksanaan program, yaitu untuk mengetahui terjadi tidaknya perubahan tersebut dilakukan penilaian untuk mengukur berhasil tidaknya program yang telah dilaksanakan tidak hanya itu terdapat penilaian dari segi-segi teknis juga dan segi-segi keperilakuan. Hal ini sesuai dengan hasil temuan penelitian bahwa memang terlihat jelas keberhasilan, kemampuan dalam melaksanakan tugas dan tidak hanya itu perubahan perilaku pun pasti ada perubahan. dalam hal ini yang menilai 
bukan hanya kami tapi terdapat beberapa pegawai dan pimpinan yang memberikan apresiasi dan pujian yang sifatnya menghibur tapi terdapat keseriusan dan itu jelas perubahannya. Disisi lain dijelaskan bahwa, terlihat jelas bahwa pegawai yang telah mengikuti pelatihan pengembangan SDM sudah bisa dikatakan berhasil baik itu di dalam kerjanya maupun secara perilakunya, karena terdapat peningkatan kinerja, dan proses perilakunya berubah. Karena di dalam program DIKLAT banyak pelajaran yang peserta/pegawai dapatkan, terkhusus dalam kinerja dan kedisiplinan itu sendiri.

Pegawai dinas Tenaga Kerja Kota Makassar konsep keberhasilan pegawai, yaitu kemampuan dalam melaksanakan tugas: yaitu semua pekerjaan yang dilakukan dapat terselesaikan dengan baik dan tepat, serta tidak adanya kesalahan dan keterlambatan dalam mengerjakan dan menyelesaikan tugasnya; perilaku: yaitu pegawai senantiasa bersikap baik, disiplin dalam segala hal dan menjalin hubungan baik dengan sesam pegawai di dalam organisasi.

Berdasarkan uraian diatas sangat jelas dilihat bahwa pegawai yang telah mengikuti pengembangan SDM melalui DIKLAT itu dapat dikatakan baik, berhasil dan memberi manfaat yang banyak bagi bagi diri sendiri maupun bagi organisasi.

\section{Pembahasan \\ Penentuan kebutuhan}

Dalam suatu upaya yang dilakukan untuk mengikuti pelatihan pengembangan SDM tentu dipilih sesuai dengan kebutuhan pegawai maupun organisasi, karena dalam pelatihan pengembangan SDM tentu pimpinan juga melihat beban kerja yang di rasakan oleh pegawai tersebut maka diikutkanlah dalam pelatihan pengembangan supaya tejadi peningkatan dalam kinerjanya. Terdapat pula kebijakan yang diberikan dari pimpinan bahwa pegawai yang diikutkan dalam pelatihan tentu telah menjadi pertimbangan dari pimpinan untuk mengikuti pegawai tersebut untuk mengikuti pelatihan pengembangan SDM tersebut.

Hal ini juga diberikan kesiapan pegawai yang akan diikutkan dalam DIKLAT seperti halnya untuk benar-benar ingin menjalani program pelatihan pengembanagan ini secara total dan diberikan penuh pertimbangan karena dalam program pelatihan pengembangan ini peserta memang fokus pada program tersebut tidak ada kesibukan ekternal selama program pelatihan ini berlangsung. Berdasarkan hasil penelitian diatas, menunjukkan bahwa pengembangan SDM melalui pendidikan dan pelatihan pada aspek penentuan kebutuhan sudah cukup baik, hal ini dilihat dari cara pimpinan menentukan pegawai yang akan diikutkan dalam program DIKLAT.

\section{Penentuan sasaran}

Berdasarkan analisis akan pelatihan dan pengembangan, berbagai sasaran ditetapkan. Sasaran yang ingin dicapai itu dapat bersifat teknikal akan tetapi dapat pula menyangkut keperilakuan. Dan mungkin juga kedua-duanya. Berbagai sasaran tersebut harus dinyatakan sejelas dan sekongret mungkin, baik bagi para pelatih dalam program pelaksanaan pelatihan pengembangan maupun bagi para peserta pelatihan pengembangan tersebut. Bagi para peserta manfaatnya terutama terlihat pada persiapan dan usaha apa yang mereka perlu lakukan agar memperoleh manfaat yang sebesarbesarnya dari pelatihan dan pengembangan yang diikutinya.

Kejelasan sasaran juga akan sangat berguna dalam hal program pelatihan dan pengembangan karena sasaran juga bisa dikatakan tujuan agar tercapai sasaran tersebut dalam mengikuti pelatihan pengembangan artinya agar program pelatihan ini diselenggarakan dengan baik dan berhasil.

Beradasrkan hasil dari penelitian, menunjukkan bahwa pengembangan SDM pada aspek penentuan sasaran sudah cukup baik, hal ini dapat dilihat dari pegawai yang telah mengikuti DIKLAT telah menemukan sasaran yang ingin di capai, seperti telah banyak mendapatkan pengalaman dan pelajaran baru.

\section{Penetapan isi program}

Pada bagian ini telah disinggung bagaimana isi program yang akan di dapatkan atau dijalankan dalam mengikuti pelaksanaan program pelatihan pengembangan SDM apakah sesuai dengan pekerjaan atau jabatan yang dijalani. Dalam program pelatihan pengembangan SDM ini tentu berdasarkan analisis penentuan kebutuhan dan sasaran yang hendak dicapai dan berdasarkan dan kedudukan jabatan di suatu organisasi/instansi tersebut. Karena hasil yang hendak di capai oleh para peserta sesuai dengan apa yang diinginkan dalam mengikuti program pelatihan pengembangan tersebut.

Berdasarkan hasil penelitian, menunjukkan bahwa pengembangan SDM melalui pendidikan dan pelatihan melalui aspek penetapan isi program sudah di jalankan dengan cukup baik, 
dimana dapat dilihat bahwa dalam program pelatihan pengembangan melalui DIKLAT ini sesuai dengan program yang akan di capai dalam program pelatihan ini.

\section{Prinsip-prinsip belajar}

Dalam hidup semua pasti punya prinsip belajar apakah prinsip belajarnya baik ataupun buruk tetapi apapun yang menjadi prinsip itu pasti memiliki tujuan. telah banyak pendapat yang mengatakan bahwa pada dasaranya prinsip belajar yang layak dipertimbangkan untuk dijadikan prinsip belajar yang baik adalah yang bisa merubah menjadi lebih baik. Adapun hasil penelitian yang telah dilakukan terdapat dua informan yang mengakui bahwa setelah mengikuti DIKLAT terdapat pula perubahan prinsip-prinsip bealajarnya. Di kalangan para pakar pelatihan pengembangan telah umum diterima pendapat yang mengatakan bahwa pada dasarnya prinsip belajar yang layak dipertimbangkan untuk di terapkan adapun salah satunya yaitu partisipasi, mengenai partisipasi sebagai salah satu prinsip belajar dapat dikatakan bahwa pada umumnya proses belajar berlangsung dengan lebih cepat dan pengetahuan atau keterampilan yang diperoleh diingat lebih lama. Misalnya, sekali seorang belajar dan menguasai teknik berenang, sepanjang hidupnya dia akan tetap bisa berenang karena partisipasinya waktu belajar.

Berdasarkan hasil penelitian, menunjukkan bahwa pengembangan SDM melalui pendidikan dan pelatihan pada penilaian prinsip-prinsip belajar sudah berjalan cukup baik, hal ini dapat dilihat dari pegawai yang telah mengikuti DIKLAT terdapat perubahan prinsip-prinsip belajar yang lebih baik dari sebelumnya.

\section{Pelaksanaan program}

Pelaksanaan program ini dilakukan tentu dengan adanya suatu kepentingan baik itu kepentingan pegewai maupun kepentingan organisasi, yang mengikutkan pegawai dalam pelatihan pengembangan SDM melalui DIKLAT. Dalam program ini organisasi maupun perusahaan pasti melakukan pelatihan pengembangan SDM agar supaya terdapat peningkatan SDM maupun organisasi itu sendiri. Dalam hal ini telah dirasakan oleh para pegawai yang telah mengikuti DIKLAT terdapat pelaksanaan program sesuai dengan bidang masing-masing pegawai/peserta.

Berdasarkan hasil penelitian, menunjukkan bahwa pelaksanaan pogram dalam upaya peningkatan SDM melalui DIKLAT sudah berjalan dengan cukup baik karena adanya kepentingan pegawai maupun organisasi dan kepentingan itu telah tercapai dengan baik dan mendapatkan hasil yang diinginkan.

\section{Identifikasi manfaat}

Dalam suatu pelaksanaan program yang telah di laksanakan perlu diadakannya mengidentifikasi manfaat, hal ini di lakukan agar dapat diketahui manfaat apa yang di peroleh dari seorang peserta tersebut setelah mengikuti program pelatihan pengembangan SDM tersebut. Dalam hal ini yang melakukan identifikasi manfaat yaitu tentunya seorang pimpinan dan pegawai/peserta yang telah mengikuti program itu sendiri.

Berdasarkan hasil penelitian, menunjukkan bahwa hasil dari identifikasi manfaat pengembangan SDM ini sudah diakatakan cukup baik. Hal ini dapat dilihat dari manfaat yang telah di capai pegawai seperti terdapat peningkatan dalam kinerjanya.

\section{Penilaian pelaksanaan program}

Dalam hal ini penilaian pelaksanaan program telah di lakukan, dan terdapat hasil yang cukup baik yang di dapatkan oleh para pegawai yang telah mengikuti DIKLAT, hal ini dilihat dari kinerja semakin meningkat dan dapat menyelesaikan tugas kantor secara tepat waktu, dan terdapat pula perubahan sikap dan perilaku disiplin dalam hal bekerja.

Berdasarkan hasil penelitian, menunjukkan bahwa hasil dari penilaian pelaksanaan program melalui DIKLAT ini sudah dikatakan cukup baik, hal ini dapat dilihat dari hasil yang didapatkan pegawai seperti peningkatan dalam kinerjanya lebih baik, dapat menyelesaikan tugas dengan cepat dan tepat dan menjadi SDM yang berkualitas dan terdapat pula perubahan perilaku disiplin dalam bekerja.

\section{KESIMPULAN DAN SARAN}

Berdasarakan hasil penelitian mengenai strategi pengembangan sumber daya manusia melalui pendidikan dan pelatihan pada Kantor Dinas Tenaga Kerja Kota Makassar, dapat disimpulkan sebagai berikut: upaya atau strategi yang dilakukan oleh Dinas Tenaga Kerja Kota Makassar dalam pengembangan Sumber Daya Manusia sudah terlaksana dengan cukup baik. Melihat dari focus dan deskripsi fokus dalam penelitian ini, yaitu: 1) penentuan kebutuhan telah ditetapkan dengan cukup 
baik, 2) penentuan sasaran yang berada dalam kategori cukup baik, 3) penetapan isi program berada dalam kategori cukp baik, 4) prinsip-prinsip belajar mendapatkan hasil yang cukup baik, 5) pelaksanaan program mendapatkan hasil yang cukup baik, 6) identifikasi manfaat mendapatkan hasil yang cukup baik, dan 7) penilaian pelaksanaan program mendapatkan hasil yang cukup baik.

\section{REFERENCES}

Bangun, W. (2016). Human resource: To increasing Indonesian competitiveness on asean economic community. International Journal of Applied Business and Economic Research.

Bertram, J., Moskaliuk, J., \& Cress, U. (2015). Virtual training: Making reality work? Computers in Human Behavior, 43, 284292. https://doi.org/https://doi.org/10.1016/j.chb .2014 .10 .032

Blaga, P., \& Jozsef, B. (2014). Human

Resources, Quality Circles and Innovation. Procedia Economics and Finance, 15, 1458-1462.

https://doi.org/https://doi.org/10.1016/S221 2-5671(14)00611-X

Ferris, G. R., Perrewé, P. L., Ranft, A. L., Zinko, R., Stoner, J. S., Brouer, R. L., \& Laird, M. D. (2007). Human Resources Reputation and Effectiveness. Human Resource Management Review, 17(2), 117-130. https://doi.org/https://doi.org/10.1016/j.hrm r.2007.03.003

Greasley, A. (2008). Operations management. In Operations Management. https://doi.org/10.4135/9781446213025

Hanrahmawan, F. (2012). Revitalisasi Manajemen Pelatihan Tenaga Kerja (Studi Kasus Pada Balai Latihan Kerja Industri Makassar). Jurnal Ilmiah Ilmu Administrasi Publik, 1(1), 78-94.

Inanna, Rahmatullah, \& Nurdiana. (2019). Pembelajaran kewirausahaan berbasis hand made. Seminar Nasional Lembaga Penelitian Dan Pengabdian Kepada Masyarakat Universitas Negeri Makassar, 173-176.

Nasrullah, M., Ilmawati, I., Saleh, S., Niswaty, R., \& Salam, R. (2018). Minat Menjadi
Guru Pada Mahasiswa Program Studi Pendidikan Administrasi Perkantoran Fakultas Ilmu Sosial Universitas Negeri Makassar. Jurnal Ad'ministrare, 5(1), 1-6.

Neal, C. P. (2009). Marketing management. In Marketing Management. https://doi.org/10.4324/9781315099200-17

Ningsi, C. A., Alhabsji, T., \& Utami, H. N. (2016). Pengaruh Pelatihan Dan Promosi Terhadap Motivasi Dan Kinerja Karyawan (Studi Pada Karyawan Pt. pln (Persero) Area Kendari). Jurnal Ilmiah Ilmu Administrasi Publik, 5(2), 131-143.

Ouellet, S., \& Vézina, N. (2014). Work training and MSDs prevention: Contribution of ergonomics. International Journal of Industrial Ergonomics, 44(1), 24-31. https://doi.org/https://doi.org/10.1016/j.erg on. 2013.08 .008

Ozkeser, B. (2019). Impact of training on employee motivation in human resources management. Procedia Computer Science, 158, 802-810.

https://doi.org/https://doi.org/10.1016/j.pro cs.2019.09.117

Rakib, M., Rombe, A., \& Yunus, M. (2016). PENGARUH PELATIHAN DAN PENGALAMAN MENGAJAR TERHADAP PROFESIONALITAS GURU (Studi pada Guru IPS Terpadu yang Memiliki Latar Belakang Pendidikan dalam Bidang Pendidikan Ekonomi). Jurnal Ad'ministrare" Jurnal Pemikiran Ilmiah Dan Pendidikan Administrasi Perkantoran", 3(2), 1-148.

Robbins, S. P., \& Coulter, M. (2012). Management. In Pearson.

Saggaf, S., Salam, R., Kahar, F., \& Akib, H. (2014). Pelayanan Fungsi Administrasi Perkantoran Modern. Jurnal Ad'ministrare, I(1), 20-27.

Salam, R. (2015). Penerapan Fungsi Administrasi Perkantoran Modern berbasis Daya Saing Organisasi dalam menyongsong MEA 2015. SEMINAR NASIONAL "Revolusi Mental Dan Kemandirian Bangsa Melalui Pendidikan Ilmu-Ilmu Sosial Dalam Menghadapi MEA 2015" Himpunan Sarjana Pendidikan Ilmu-Ilmu Sosial Indonesia, 1, 186-190.

Singodimendjo. (2011). Manajemen Sumber Daya Manusia. Bumi Aksara.

Suhariadi, F. (2013). Manajemen Sumber Daya Manusia: Dalam Pendekatan TeoritisPraktis. Airlangga University Press. 
Sulistiyani, A. T., \& Rosidah. (2013).

Manajemen Sumber Daya Manusia.

Gadjah Mada University Press.

Todericiu, R., Lucia, F., \& Stăniţ, A. (2014).

Reflections on Human Resources - Vital

Intangible Assets of Organizations.

Procedia Economics and Finance, 16,

575-579.

https://doi.org/https://doi.org/10.1016/S221

2-5671(14)00842-9

Yulianti, Thaief, I., \& Rahmatullah. (2019).

Contextual Teaching Learning Dalam

Pembelajaran Ekonomi Contextual

Teaching Learning in Economic Learning.

Pinisi Business Administration Review,

1(2), 117-124. 